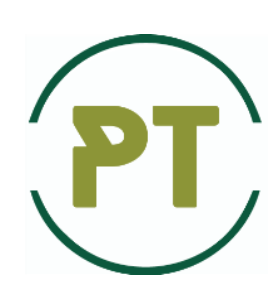

\author{
Problems of Tribology \\ Website: http://tribology.khnu.km.ua/index.php/ProbTrib \\ E-mail: tribosenator@gmail.com
}

DOI: https://doi.org/10.31891/2079-1372-2020-96-2-6-11

\title{
Analysis of the influence of surface plastic deformation on increasing the wear resistance of machine parts
}

\author{
D. Marchenko*, V. Artyukh, K. Matvyeyeva \\ Mykolayiv National Agrarian University, Mykolayiv, Ukraine \\ *E-mail: marchenkodd@mnau.edu.ua
}

\begin{abstract}
The article provides a review of information materials on the effectiveness of surface plastic deformation in order to increase the wear resistance of friction pairs. The analysis revealed that the increase in the wear resistance of parts by surface plastic deformation is significantly affected by the stabilization of the rolling forces, as well as the values of the optimal modes of rolling parts by rollers.
\end{abstract}

Key words: deformation, wear resistance, plastic deformation, hardening, roller, device.

The problem of increasing wear resistance is becoming increasingly important, as the intensity of the equipment is constantly growing. The extension of the service life of parts can be obtained by improving the surface roughness characteristics by the method of surface plastic deformation (SPD).

The combination of finishing and hardening rolling around with rollers makes it possible to obtain optimal roughness characteristics of the rolled surface and the greater depth of the hardened surface layer and leads to an increase in both wear resistance of parts and their fatigue strength.

There are three types of wear: mechanical, molecular-mechanical and corrosion-mechanical. The most common is a mechanical wear. Its varieties are abrasive, hydroabrasive, erosive fatigue, cavitation wear $[1,2]$. The largest number of machine parts works in conditions of mechanical wear. These parts, as a rule, are rolled around with a roller or smoothed with a diamond tip to reduce wear.

A great influence on the wear resistance during mechanical wear has a surface microgeometry. Moreover, if the fatigue resistance of parts increases with a decrease in roughness, then for parts that work for wearing, there is an optimal roughness parameter at which the wear is the smallest.

Most SPD methods not only reduce the roughness parameter by 5 to 10 times, but also create a shape of micro roughness that is favorable for wear resistance, which is closer than with other finishing methods to the shape of micro roughness that is created after running in.

The hardness of the surface layer, its microstructure and chemical composition of the metal have a great influence on the wear resistance. The wear resistance of steels is directly proportional to their abrasion ability, which is directly related to hardness.

Processing of SPD parts increases the surface hardness to $40-70 \%$, as a result of which, in almost all cases, the wear resistance increases $[2,3,4]$.

An increase in the number of carbide-forming alloying elements in steels and cast iron leads to an increase in the dispersion of the structure and helps to increase their wear resistance. A similar structure of the surface layer is formed after processing parts of the SPD, which contributes to an increase in their wear resistance $[3,5,6]$.

Rolling of parts made of medium carbon steel increases the wear resistance in comparison with grinding by 1,5 - 2,5 times, and in comparison with polishing - by 1,3-1,6 times (with the same surface roughness).

The increase in wear resistance is achieved during processing by almost all methods of SPD, except for shock, when the surface roughness increases (processing by shot, chasing). The latter methods in some cases require additional processing to achieve the desired roughness parameter.

A significant increase in wear resistance was also found when cast iron hardened under mixed friction conditions, where wear was studied at a specific pressure of $1,3 \mathrm{MPa}$ and a sliding speed of $0,2 \mathrm{~m} / \mathrm{s}$ on a machine with reciprocating motion, which simulates the operation of guiding metal cutting machines. Samples were 
riveted by ball head rolling. It is shown that with a certain degree of deformation, wear decreases, then increases again. Some authors $[7,8]$ believe that an increase in the wear resistance of parts with hardening occurs as a result of enhanced diffusion of atmospheric oxygen into the hardened metal and the formation of oxides such as $\mathrm{FeO}, \mathrm{Fe}_{2} \mathrm{O}_{3}$ and $\mathrm{Fe}_{3} \mathrm{O}_{4}$ in it. Such compounds are also characteristic of oxidative wear, at which the wear resistance is maximum. The preliminary hardening of the metal prevents the development of plastic deformation of the metals of the rubbing parts, which causes setting, which is the most intense type of wear [9].

Rolling in with an increase in rolling force from 0,40 to $1,0 \mathrm{kN}$ increase the wear resistance by $23-94,5$ $\%$. In these works, the tip from the Rockwell device from VK-6 alloy with a cone tip angle of $120^{\circ}$ and a radius of curvature of $0,1 \mathrm{~mm}$ was used as an abrasive tip.

Let us consider in more detail the results of studies taking into account the regimes of running in and friction conditions.

V.V. Ivanov conducted research on wear on a friction machine of the MI type of polished and rolled samples with a diameter of $55 \mathrm{~mm}$ and a width of $10 \mathrm{~mm}$. The run-in was carried out using rollers with a diameter of $170 \mathrm{~mm}$ with a profile radius of $40 \mathrm{~mm}$ and with a run-in force of 10 to $20 \mathrm{kN}$. According to his data, during dry friction paired with a cast-iron liner at a specific pressure of 1,35 $\mathrm{MPa}$, rolled samples of steel 45 turned out to be more wear-resistant in comparison with polished ones. In this case, an increase in the rolling force led to a decrease in wear resistance, which causes the phenomenon of re-riveting. In the case of lubrication in run-in samples, an increase in wear resistance by $75 \%$ is also observed in comparison with polished ones $[4,5$, $6]$.

V.S. Rystsova investigated the wear of treated samples (with a diameter of $30 \mathrm{~mm}$ ) of steels 45 and U8 during heavy lubrication with spindle oil. Samples were previously tempered in vacuo. Some of the samples were tested after grinding, others after rolling around with a ball (with a diameter of $12 \mathrm{~mm}$; with a rolling force of $0,6 \mathrm{kN}$ ). Wear tests performed on a MI-type machine at a specific pressure of 1,2 MPa and a speed of $200 \mathrm{rpm}$ paired with cast-iron blocks showed that the samples rolled from a ball made of steel 45 got about 2,5 times more wear compared to wear polished samples. In the case of rolled samples of U8 steel, on the contrary, the wear was approximately 2,5 times lower than that of polished ones, this is due to the fact that high waviness appeared on the surface of the sample of steel 45 .

E.G. Konovalov tested for wear segment samples of carbon steels 15; 35; 45 paired with cast-iron cylindrical lapping when lubricated with machine oil. Samples were cut from bushings, the inner diameter of which was ground or rolled by a roller. Wear occurred within 6 hours at a specific pressure of $10 \mathrm{MPa}$, a sliding speed of $34.5 \mathrm{~m} / \mathrm{min}$. Run-in samples of all steels were more wear-resistant than polished ones. In this case, the highest wear resistance (2,8 times higher than polished ones) was acquired by samples made of steel 45 , and the smallest - from steel 15. The decrease in the efficiency of rolling in samples from mild steel 15, according to E.G. Konovalov, is explained by its high sensitivity to re-riveting, which arose in the process of wear.

According to the data of V.K. Lazarenko and G.A. Preis, during sliding friction with velocities of 0,25 and 1,5 m/s and specific pressure of 1,5 MPa, samples from different steels (steel 45, SHX15, 18HGT, X12M, CVG) after rolling around them with a roller, they increased their wear resistance by $14-28 \%$, and after shot blasting - by $15-20 \%$. At a sliding speed of $5,08 \mathrm{~m} / \mathrm{s}$, the shot peening did not affect the wear resistance, and rolling around with a roller led to an increase of only 5-6\%. Considering that wear occurred in the absence of lubrication, the benefits of running in are obvious. An insignificant effect at a sliding speed of 5,08 $\mathrm{m} / \mathrm{s}$ can be explained by the high temperature in the contact of the rubbing surfaces.

The experiments performed at the Belarusian Institute of Agricultural Mechanization during friction with oil supply showed a decrease in the wear of rolled-in samples of steel 15;35; 45 and 45G2 in comparison with polished ones. The greatest wear resistance was obtained by samples run-in with pressure, which ensures the creation of minimal roughness.

Tests of rolled samples of steel 45, carried out by V.K. Lazarenko et al., show that the resistance to abrasive wear depends on the degree of hardening. With an increase in microhardness during rolling by $42 \%$, the wear resistance increased by $94,5 \%$.

Given the presence of conflicting data, special experiments were conducted to study the effect of rolling by a toroidal roller on the wear resistance of friction pairs [3]. During sliding friction, samples of normalized steel 45 were tested for wear paired with a gray cast iron insert of grade SCh 18-36, and samples of hardened steel $40 \mathrm{H}$ were paired with a bronze insert. The tests took place on an MI friction machine for eight hours with plentiful lubrication. Samples with a diameter of $40 \mathrm{~mm}$ were rolled in at different rolling pressures. For comparison, polished samples were also tested. Tests have shown that rolling hardening is a reliable means of increasing the wear resistance of parts. Despite the high specific pressure during sliding (samples of steel 45 were tested at a pressure of $10 \mathrm{MPa}$, and samples of steel $40 \mathrm{H}$ at a pressure of 2,5 and 5,0 $\mathrm{MPa}$ ), wear after rolling compared to wear after grinding decreased for steel 45 by $26 \%$, and for steel $40 \mathrm{H}$ - by $37 \%$.

The highest wear resistance in both cases was acquired by the samples run-in at the optimum pressure in the contact (from 150 to $200 \mathrm{MPa}$ ). Exceeding this pressure makes the surface less wear-resistant. For example, an increase in pressure during the testing of samples of steel 45 from 220 to $240 \mathrm{MPa}$ led to a slight increase in wear.

A study of the state of the surface layer of hardened samples showed its structural heterogeneity. The latter, in particular, is characterized by a wide spread of microhardness and is a consequence of grinding defects. 
As a result of rolling in, the spread of hardness is significantly reduced, which indicates the formation of a more uniform (structurally) surface layer by rolling. This circumstance should be considered one of the main factors in increasing wear resistance.

An increase in the wear resistance of run-in hardened samples was also established by V.A. Sologub, I.I. Sukhanov and others. V.A. Sologub tested samples of alloy steel 5KHV2S in a pair with a holder of steel R18 on a friction machine of MI type at a pressure of 5,0 MPa with grease. He obtained an increase in wear resistance as a result of running in. Optimum, from the point of view of wear resistance, was a break-in force of 2,0 kN (with a roller diameter of $50 \mathrm{~mm}$ and a profile radius of $8 \mathrm{~mm}$ ). The increase in wear resistance is characterized by higher structural homogeneity and the presence of residual compressive stresses formed during rolling.

The study of the wear resistance of the guide blocks of dies made of SHX15 steel, heat-treated to a hardness of HRC $62-64$, was carried out with back-and-forth movement with a frequency of 230 strokes/min $[1,2,3]$. The wear of guides hardened by rolling in a vibrating ball (with a frequency of $18-24 \mathrm{kHz}$ ), in comparison with the wear of polished ones, is reduced by $2-4,7$ times.

Thus, the rolling-in of friction surfaces of parts made of mild and hardened steels in most cases should be considered a reliable means of increasing wear resistance.

Small rolling wear is most characteristic of rolling friction, which is expressed in surface chipping of metal particles. The question of the effect of previous hardening on this type of wear is not well understood.

L.M. Shkolnik and V.I. Shakhov cite data that show the negative impact of hardening. For example, in samples of high-carbon bandage steel, as a result of rolling with a force of $10 \mathrm{kN}$, the wear resistance decreases by half compared with non-rolled samples, in this case the phenomenon of re-riveting occurred. In other cases, the preliminary hardening of specimens of cemented steels $18 \mathrm{Kh} 2 \mathrm{~N} 4 \mathrm{VA}$ and $12 \mathrm{Kh} 2 \mathrm{~N} 4 \mathrm{~A}$ practically did not change the contact endurance. The authors believe that during friction of rolling in the surface layers of parts, the same phenomena occur as during rolling by rollers. This leads to high stresses, delamination of the surface layers and chipping. Therefore, they do not recommend the use of hardening for wear-like wear. However, tests when the balls were rolling along the sample at a speed of $2 \mathrm{~m} / \mathrm{s}$ with a maximum operating voltage of $\sigma_{\max }=45 \mathrm{MPa}$ in the absence of lubrication yielded results opposite to those discussed above. According to the data of V.K. Lazarenko and G.A. Preis, for samples with steels 45, 37KhNZA, 20Kh, 40Kh, 12KhNZA and ShKh15, which were subjected to shot peening, the relative wear resistance increased from 25 to $116 \%$.

A.S. Venzhega tested polished and rolled samples made of $9 \mathrm{H}$ steel hardened by high-frequency currents. The rolling was carried out by a roller with a profile radius of $4,5 \mathrm{~mm}$ with a rolling force of 0,5 to $4,0 \mathrm{kN}$. The highest wear resistance, 2,5 times higher than for polished ones, was established for samples run in with a force of $2, \mathrm{kN}$. The greatest increase in hardness was consistent with this effort. A.S. Venzhega associates the increase in wear resistance with an increase in the structural uniformity of the surface layer and the presence of residual compressive stresses in it. A batch of roll-rolled rolls of a 12-roll mill was also tested. The rolled-in rolls during brass rolling turned out to be $38 \%$ more durable than polished ones.

Tests of wear resistance during rolling friction were carried out on a MI-1M machine. Samples with steels 14Kh2NZMA and ShKh15 with a diameter of $40 \mathrm{~mm}$ and a width of $10 \mathrm{~mm}$ were studied. The upper samples were made under identical conditions from the same materials. The lower samples made under different conditions had a different surface layer.

Samples of steel 14Kh2NZMA were grinded after cementation and heat treatment. Some samples were tested immediately after grinding, while others were tested at different pressures before testing. The hardness of the samples before rolling in was HRC $58-59$.

After quenching and tempering, steel samples SHX15 (HRC 61 - 62) were processed according to three options: subjected to grinding, grinding with the following polishing, and grinding with the following rolling around with a ball with a diameter of $10 \mathrm{~mm}$.

During testing, the load on the lower specimen was carried out by pressing a roller against it using a calibrated spring. Contact pressure was $85 \mathrm{MPa}$. During wear, the sample rotated at a speed of $416 \mathrm{rpm}$.

The wear resistance of the samples was evaluated by the amount of worn metal by weighing the samples on an analytical balance. The test sample was dipped in a bath with motor oil. The duration of testing samples made of ShKh15 steel was 32 hours, and from steel 14Kh2NZMA -8 hours. The samples received the greatest wear after grinding according to the technology used at the plants. In the samples run-in after grinding, wear decreased by $32-57 \%$. The increase in pressure during the run-in provides higher wear resistance. So, in samples from steel 14Kh2NZMA rolled in at a pressure of $150 \mathrm{MPa}$, wear compared to polished ones decreased by $32 \%$, and rolled in at a pressure of $280 \mathrm{MPa}$ - by $51 \%$.

The greatest wear resistance was shown by the samples run-in at a pressure of $200 \mathrm{MPa}$. An increase in pressure up to $300 \mathrm{MPa}$ leads to a certain decrease in the efficiency of rolling. Obviously, this is due to reriveting, the result of which is a slight decrease in the hardness of the surface layer and residual compressive stresses.

It should be emphasized that the spread in microhardness of the rolled samples is insignificant in comparison with the spread in microhardness of polished samples.

A sharp increase in the wear resistance of hardened samples by the SPD method of steel SHX15 (with hardness HRC 64 - 67) was also established in [7, 8,9]. The samples were run in a roller with a profile radius of $16 \mathrm{~mm}$. Wear was carried out by rolling a ball with a diameter of $10 \mathrm{~mm}$ in the presence of lubricant and was 
estimated by the size of the groove formed. The number of cycles in all tests was taken equal to 105 , the contact force $-0,35 \mathrm{kN}$. The wear resistance of the rolled-in samples was higher than the wear resistance of polished ones by $1,6-4,6$ times.

To check the influence of rolling on the wear resistance of a screw pair of friction under conditions of abrasive wear, studies were carried out under industrial conditions of the wear resistance of screw pairs on a tilter of flasks [2]. The loading scheme of screw pairs is shown in Fig. 1.

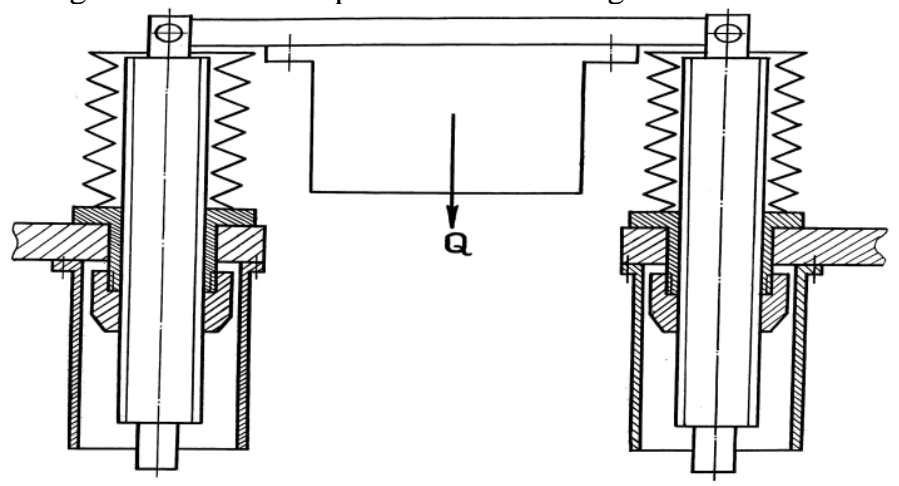

Fig. 1. Scheme of loading screw pairs

The data on the wear of the tested screw pairs of the flask tilter are given in table 1 .

Table 1

Wear flange screw pairs

\begin{tabular}{|c|l|c|c|c|c|c|}
\hline \multirow{2}{*}{ Wear part } & \multirow{2}{*}{ Nut material } & \multicolumn{2}{|c|}{ Non-rolled screw } & \multicolumn{2}{c|}{ Round-rolled screw } & $\begin{array}{c}\text { Relative increase } \\
\text { in service life, } \%\end{array}$ \\
\cline { 3 - 7 } & & $\begin{array}{c}\text { Duration of } \\
\text { work, shifts }\end{array}$ & $\begin{array}{c}\text { Wear, } \\
\mathrm{mm}\end{array}$ & $\begin{array}{c}\text { Duration of } \\
\text { work, shifts }\end{array}$ & $\begin{array}{c}\text { Wear, } \\
\mathrm{mm}\end{array}$ & \\
\hline \multirow{3}{*}{ Screw } & Bronze & 144 & 0,64 & 289 & 0,68 & 78 \\
& AZhMts10-3-1.5 & 268 & 0,68 & 404 & 0,88 & 76 \\
\cline { 2 - 7 } & Cast iron & 106 & 6,1 & 144 & 3,8 & 54 \\
\hline \multirow{3}{*}{ Nut } & Bronze & 225 & 0,64 & 186 & 0,61 & 50 \\
\cline { 2 - 7 } & AZhMts 10-3-1.5 & 228 & 0,94 & 195 & 0,60 & 114 \\
\hline \multirow{2}{*}{$\begin{array}{c}\text { Bronze } \\
\text { extension }\end{array}$} & Cast iron & 192 & 7,7 & 225 & 4,4 & 30 \\
\hline
\end{tabular}

The wear of the screws for the overhaul period is $0,4-1,0 \mathrm{~mm}$. Replacing bronze nuts with cast iron leads to an increase in screw wear by $35-50 \%$. Under the same wear conditions, the resistance of rolled screws working together with bronze nuts is higher than non-rolled screws by $78 \%$, working together with cast-iron nuts - by $54 \%$. The wear resistance of cast-iron nuts is slightly higher than that of bronze ones. However, due to the low resistance to bending load, the durability of cast iron nuts may decrease as a result of an incompletely worn turn. The relative increase in the durability of nuts as a result of rolling in the screw is the same as for the screws themselves.

Fig. 2. and Fig. 3 present sections of cast-iron nuts and extensions that were installed to work with new nuts and served as "witnesses" to their wear. As it can be seen from the figures, the extensions that worked with the rolled-in screw had less wear than those that worked with the rolled-in screw.

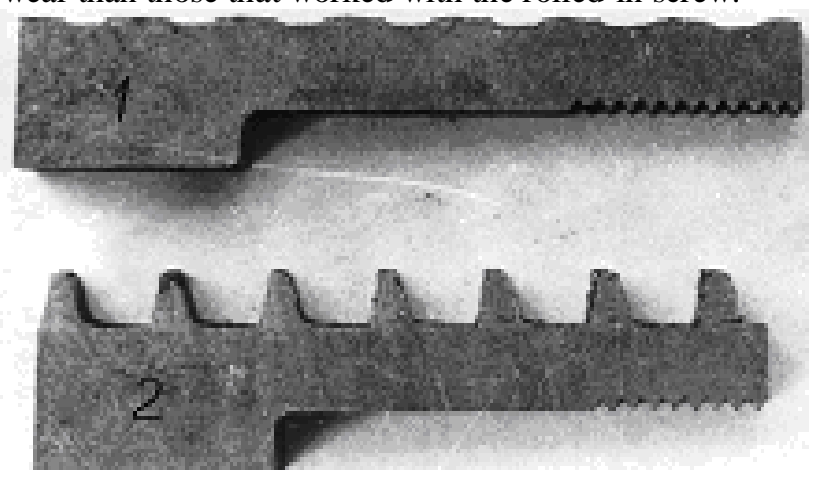

Fig. 2. Section of cast-iron nuts:

1 - after 192 shifts of work with a non-rolled screw (wear was 7,2 mm);

2 - after 225 shifts of work with a run-in screw (wear was $3,8 \mathrm{~mm}$ ) 


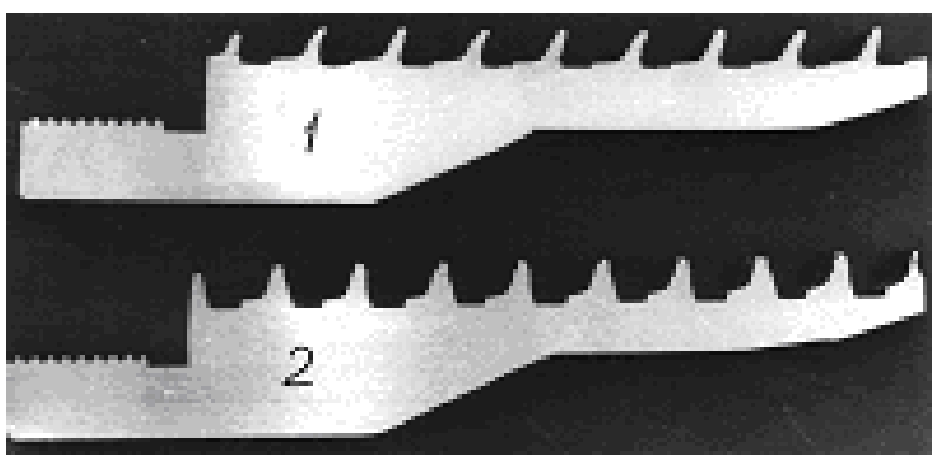

Fig. 3. Section of bronze extensions:

1 - after 106 shifts of work with a non-rolled screw (wear was $6,1 \mathrm{~mm}$ ); 2 - after 114 shifts of work with a run-in screw (wear was $3,8 \mathrm{~mm}$ )

Based on the above material, it can be concluded: the wear resistance of friction pairs as a result of the SPD of one of the parts increases due to an increase in the supporting surface in the contact of friction pairs with an increase in the radius of curvature of the protrusions of the roughness, the absence of waviness on the rolled surface, and also due to the hardening of the metal of the surface layer. The increase in the wear resistance effect of the riveted surface layer, as it can be seen from the review, also belongs to the residual compressive stresses that are created as a result of plastic deformation. The hardening of the parts prevents the setting that occurs during friction by eliminating the plastic deformation of the surface layer of the part.

\section{Refrences} $-132 \mathrm{~s}$.

1. Papshev D.D. Uprochnenie detalej obkatkoj sharikami / D.D. Papshev. - M.: Mashinostroenie. - 1968.

2. Babej Ju.I. Poverhnostnoe uprochnenie metallov / Ju.I. Babej, B.I. Butakov, V.G. Sysoev. - Kiev: Nauk. dumka, 1995. - 256 s.

3. Butakov B.I. Usovershenstvovanie processa chistovogo obkatyvanija detalej rolikami / B.I. Butakov // Vestnik mashinostroenija. - 1984. - № 7. - S. 50 - 53.

4. Shnejder Ju.G. Chistovaja obrabotka metallov davleniem / Ju.G. Shnejder. - M.: Mashinostroenie, 1963. $-272 \mathrm{~s}$.

5. Balter M.A. Uprochnenie detalej mashin / M.A. Balter. - M.: Mashinostroenie, 1978. - $184 \mathrm{~s}$.

6. Odincov L.G. Uprochnenie i otdelka detalej poverhnostnym plasticheskim deformirovaniem / L.G. Odincov. - M.: Mashinostroenie, 1987. - 328 s.

7. Konovalov E.G. Osnovy novyh sposobov metalloobrabotki / E.G. Konovalov. - Minsk: Iz - vo AN BSSR, 1961. - $185 \mathrm{~s}$.

8. Braslavskij V.M. Volnistost' poverhnosti pri obkatke rolikami / V.M. Braslavskij // Stanki i instrument. - 1960. - № 6 - S. $15-20$.

9. Shkol'nik L.M. Tehnologija i prisposoblenija dlja uprochnenija i otdelki detalej nakatyvaniem / L.M. Shkol'nik, V.I. Shahov. - M.: Mashinostroenie. - 1964. - 184 s.

10. Marchenko D.D. Improving the contact strength of V-belt pulleys using plastic deformation / D.D. Marchenko, K.S. Matvyeyeva // Problems of Tribology. - Khmelnitsky, 2019. - Vol 24. - No 4/94 (2019) - S. 49-53. DOI: https://doi.org/10.31891/2079-1372-2019-94-4-49-53.

11. Zubiekhina-Khaiiat A.V. Mathematical modeling of the process of rolling body rolls with needed rollers / A.V. Zubiekhina-Khaiiat, D.D. Marchenko // Problems of Tribology. - Khmelnitsky, 2019. - Vol. 24. No 3/93 (2019) - S. 45-50. DOI: https://doi.org/10.31891/2079-1372-2019-93-3-45-50.

12. Kuz'menko A. G. Zakonomernosti proskal'zyvanija pri vnutrennem i naruzhnom kachenii cilindrov. Jeksperiment (Chast' 1) / A. G. Kuz'menko // Problemi tribologiï. - Hmel'nic'kij, 2012. - № 2. - S. 121-126.

13. Marchenko D.D. Investigation of wear of a contact pair of friction "rope block - rope" / D.D. Marchenko // Problems of Tribology. - Khmelnitsky, 2019. - Vol 24. - No 2/92 (2019) - S. 82-87. DOI: https://doi.org/10.31891/2079-1372-2019-92-2-82-87. 
Марченко Д.Д., Артюх В.А., Матвеева К.С. Анализ влияния поверхностной пластической деформации на повышение износостойкости деталей машин.

В статье приведен обзор информационных материалов по эффективности применения поверхностного пластического деформирования с целью повышения износостойкости пар трения. При анализе было выявлено, что на повышение износостойкости деталей поверхностным пластическим деформированием в значительной степени влияют стабилизация усилия обкатывания, а также значения оптимальных режимов обкатывания деталей роликами.

Ключевые слова: деформация, износостойкость, пластическое деформирование, упрочнение, ролик, устройство 